\title{
Biomass production and nutritional quality of potato tuber as affected by blended fertilizer (NPSB), cattle manure, vermicompost and mineral NP in southwestern Ethiopia
}

\author{
Isreal Zewide ${ }^{1}$, Sanjay Singh ${ }^{2 *} \&$ Henok Kassa $^{3}$ \\ ${ }^{1}$ Department of Horticulture, College of Agriculture and Natural Resources, Mizan-Tepi University, Mizan Teferi, Ethiopia \\ ${ }^{2}$ Department of Plant Science, College of Agriculture and Natural Resources, Mizan-Tepi University, Mizan Teferi, Ethiopia \\ ${ }^{3}$ Department of Natural Resources Management, College of Agriculture and Natural Resources, Mizan-Tepi University, Mizan Teferi, Ethiopia \\ *Email: sanju80gon@gmail.com
}

\section{ARTICLE HISTORY}

Received: 10 December 2020 Accepted: 02 May 2021

Available online: 01 July 2021

\section{KEYWORDS}

Blended fertilizer

Biomass yield

Crude protein

Starch

Total soluble solids

\begin{abstract}
Keeping in view the declining soil fertility and people's nutritional issues, a research experiment on potato (Solanum tuberosum L.) was carried out in Belg (February to May) and Meher (June to October) seasons of 2020 at Abelo in Masha district, southwestern Ethiopia, to gauge the effects of blended mineral NPSB fertilizer, cattle manure (CM), vermicompost (VC) and mineral NP on growth, biomass and tuber nutritional quality. The fertilizer treatments consisted of $7.5 \mathrm{t} \mathrm{CM} \mathrm{ha}^{-1}+75$ and $50 \%$ of recommended dose of NP fertilizers (RDF), $7.5 \mathrm{t} \mathrm{VC} \mathrm{ha}^{-1}+75,50$ and $25 \%$ of NP, $5 \mathrm{t} \mathrm{VC} \mathrm{ha-1}+75 \% \mathrm{NP}$, $100 \mathrm{~kg} \mathrm{NPSB} \mathrm{ha}^{-1}+61.5 \mathrm{~kg} \mathrm{P} \mathrm{ha}^{-1}+146 \mathrm{~kg} \mathrm{~N} \mathrm{ha}^{-1}, 150 \mathrm{~kg} \mathrm{NPSB} \mathrm{ha}^{-1}+53.7 \mathrm{~kg} \mathrm{P} \mathrm{ha}^{-1}+138 \mathrm{~kg} \mathrm{~N} \mathrm{ha}^{-1}, 200$ kg NPSB ha ${ }^{-1}+46 \mathrm{~kg} \mathrm{P} \mathrm{ha}^{-1}+128 \mathrm{~kg} \mathrm{~N} \mathrm{ha}^{-1}, 100 \%$ of NP $\left(165 \mathrm{~kg} \mathrm{~N} \mathrm{ha}^{-1}+60 \mathrm{~kg} \mathrm{P} \mathrm{ha}^{-1}\right)$ and one nofertilizer treatment (control) making a total of 11 treatments. The effects of the treatments indicated that the application of $75 \%$ of NP and $7.5 \mathrm{t} \mathrm{ha}^{-1}$ vermicompost significantly increased the plant height, dry shoot and root yields, specific gravity, total soluble solids and starch. On the other hand, the highest crude protein content was recorded at the application of $200 \mathrm{~kg} \mathrm{NPSB} \mathrm{ha}^{-1}+46 \mathrm{~kg} \mathrm{P} \mathrm{ha}^{-1}+128$ $\mathrm{kg} \mathrm{N} \mathrm{ha}^{-1}$. It was summarized that the use of $7.5 \mathrm{t} \mathrm{VC} \mathrm{ha}^{-1}+75 \%$ of NP (124 kg N ha- ${ }^{-1}$, and $\left.45 \mathrm{~kg} \mathrm{P} \mathrm{ha}^{-1}\right)$ increased the biomass and improved the quality of potato fetching high economic return over the sole application of either $200 \%$ mineral NPSB ha ${ }^{-1}$ or $150 \%$ mineral NPSB ha ${ }^{-1}$ or $100 \%$ NP or no-application of fertilizer in the study area. In the light of present findings, there is a need to extend these studies using multiple combination ratios of NPSB fertilizer with vermicompost and cattle manure on different soils of varied agro-climatic zones to come up with conclusive recommendations.
\end{abstract}

\section{Introduction}

Potato is a leading staple food in the world population and it is the second after maize in terms of the number of producer countries (1). Potato is a rich source of energy and supplies many essential nutrients including potassium, phosphorus, manganese, magnesium and vitamins C, B6 and folate (2). In Ethiopia, potato is extensively grown in central, eastern, northwestern and southern parts of the country and these areas together cover approximately $83 \%$ of the potato farmers. The southern state SNNPR of the country accounts for about $16.62 \%$ of the potato production. However, farmers also produce different crops like enset, maize, wheat, barley, bean, pea, coffee, haricot bean and fruits and vegetables. Among vegetables such as potato, onion, cabbage, beet root, tomato and carrot; potato is the dominant vegetable crop whereas, fruit crops such as papaya, mango, avocado and coffee are important cash crops of smallscale farmers in the study area. In spite of such a substantial potential for potato production, the productivity is very low (13.8 t ha-1) as compared to the world average tuber yield of $\left(19 \mathrm{t} \mathrm{ha}^{-1}\right)$ (3). The most limiting factor for potato productivity is the declining soil fertility of Masha district (4). Undoubtedly, Ethiopia inherits a low input-based farming system and the cultivated lands have been supporting agricultural production for decades which has resulted in significant loss of natural fertility. Moreover, the rapid growth of population has necessitated the regular cultivation of fallow lands without the restoration of soil fertility causing nutrient deficiencies in soils. Although efforts are made to come up with improved production technologies, the productivity of potatoes in production fields has remained very low (5). Thus, the

(c) Zewide et al (2021). This is an open-access article distributed under the terms of the Creative Commons Attribution License, which permits unrestricted use, distribution and reproduction in any medium, provided the original author and source are credited (https://creativecommons.org/licenses/by/4.0/). 
soil fertility decline in subsistence farmers' field is felt as the major limiting factor for the low crop productivity in general and the productivity of potatoes in particular with respect to Sheka Zone, southwestern Ethiopia.

Thus, improving food production and soil resources has become an enormous challenge in the study area. Therefore, a strategy that includes a soil fertility replenishment program having the potential to supply nutrients and arrest the mining of soil fertility is preferable. There is, therefore, a need to take measures to reverse this trend. Due to the decreased use of organic matter like crop residues, cattle manure, compost, etc., there is a great increase in nutrient depletion, therefore the application of organic manure is a crucial component of soil fertility and crop yield (6). Further, sulfur is also an important nutrient for plant growth whose content varies from 0.2 to $0.5 \%$ in plant tissues. Sulfur has been found to be an indispensable element for crop production and it is an integral part of proteins, sulpholipids, enzymes etc. (7). Its fertilization helps to enhance the uptake of $\mathrm{N}, \mathrm{P}, \mathrm{K}$ and $\mathrm{B}$ in the plant which results in increased crop productivity. Sulfur application at $45 \mathrm{~kg} \mathrm{ha}^{-1}$ in potato has given the highest tuber yield, large and medium-size tubers yield, biomass, specific gravity, sugar and starch contents (8).

The integrated use of $611 \mathrm{~kg}$ lime $+2.5 \mathrm{t}$ compost $+75 \mathrm{~kg} \mathrm{NPSB}+50 \mathrm{~kg} \mathrm{KCl}+36 \mathrm{~kg} \mathrm{~N}^{-1}$ have been recommended for higher barley production in acid soil (9). Similarly, grain and straw yields and nutrient (NPKS) uptake by rice crop were significantly increased due to the application of manures or bioslurries with chemical fertilizers (10). In other agricultural approaches to enhance the nutrient availability, the strategy of the mixed fertilizer and biofertilizer Trichoderma-enriched fertilizer application or the inoculation of rhizobacteria is also gaining popularity in different countries. It has been found that microorganisms and plant growth promoting rhizobacteria (PGPR) Bacillus spp. enhance nutrient availability, nutrient use efficiency and increase the growth and yield of plants $(11,12)$. It has also been reported that Bacillus cereus and Klebsiella variicola were efficient in plant growth promoting activities. The use of PGPR, i.e. B. cereus and $K$. variicola significantly increased plant growth and $\mathrm{Fe}, \mathrm{Zn}, \mathrm{Ca}, \mathrm{Mg}, \mathrm{Cu}, \mathrm{Na}$ and $\mathrm{K}$ contents of tomato plants (13). The field experiment on potato crop demonstrated that reproductive growth restricts vegetative growth and reduces tuber yield and dry matter content of potato. Fruiting in crop reduced tuber specific gravity and dry matter content while increased $\mathrm{P}, \mathrm{K}, \mathrm{Mg}, \mathrm{Fe}$ and $\mathrm{Mn}$ content of the tubers. Reproductive growth did not affect tuber $\mathrm{Ca}, \mathrm{S}, \mathrm{Cu}$ and $\mathrm{Zn}$ concentrations (14).

The incorporation of organic and inorganic fertilizers apart from supplying essential nutrients it also creates some positive synergetic effect on crop yield and improves soil physical and chemical properties. Thus, there is a need to understand the effects and identify the optimum rates of the newly introduced NPSB fertilizer that contains sulfur and boron for economical production of potatoes.
Moreover, information on the effect of the application of cattle manure, vermicompost, mineral NP and NPSB fertilizers on the growth and nutritional quality of potato tubers is highly imperative too.

\section{Materials and Methods}

\section{About study site}

A farmer's field at Abelo kebele in Masha district was chosen for the experiment conducted in Belg (February to May) and Meher (June to October) cropping seasons during 2020 under rainfed conditions. The research site is located at $7^{\circ} 44^{\prime} 1714^{\prime \prime} \mathrm{N}$ latitude and 35'30'16” $\mathrm{E}$ longitude. The total rainfall was $607.2 \mathrm{~mm}$ in Belg and $953.31 \mathrm{~mm}$ in Meher growing season. The maximum temperatures during cropping seasons varied from $23.97^{\circ} \mathrm{C}$ (May) to $24.84^{\circ} \mathrm{C}$ (February) and $24.39^{\circ} \mathrm{C}$ (June) to $26.02{ }^{\circ} \mathrm{C}$ (October) with a mean maximum temperature of $24.57^{\circ} \mathrm{C}$ and $25.38^{\circ} \mathrm{C}$ in Belg and Meher seasons, respectively. The minimum temperatures varied between $17.13^{\circ} \mathrm{C}$ (May) to $17.54^{\circ} \mathrm{C}$ (February) in Belg and $14.93{ }^{\circ} \mathrm{C}$ (June) to $15.76{ }^{\circ} \mathrm{C}$ (October) in Meher season with a mean minimum temperature of $17.29^{\circ} \mathrm{C}$ and $16.21^{\circ} \mathrm{C}$ in Belg and Meher seasons, respectively (Fig. 1).

\section{Experimental materials}

Urea $(46 \% \mathrm{~N})$, triple superphosphate $(20 \% \mathrm{P})$ and NPSB (18.1\% N-5.7\% P-6.7\% S-0.71\% B) fertilizers were used apart from cattle manure (CM) and vermicompost (VC) as organic fertilizers. 'Belete' potato variety was used for the study which was released by Holeta Agricultural Research Center, Ethiopia in 2009. The variety matures in 90 to 120 days and gives an average yield of $29.13 \mathrm{t} \mathrm{ha}^{-1}$ on farmers' field and $44.8 \mathrm{t} \mathrm{ha}^{-1}$ on the research field (15).

\section{Treatment and experimental design}

Six fertilizer treatments, three blended fertilizer treatments and two controls, i.e. 100\% NP (165 kg N $\mathrm{ha}^{-1}+60 \mathrm{~kg} \mathrm{P} \mathrm{ha}{ }^{-1}$ ) and no-fertilizer (control treatment) making a total of 11 treatments were arranged (Table 1). The experiment was laid out, exercising all precautions needed for the field experiments, in a randomized complete block design with three replications. The fertilizer was used at the rate of $61.5 \mathrm{~kg} \mathrm{P} \mathrm{ha}^{-1}+146 \mathrm{~kg} \mathrm{~N} \mathrm{ha}^{-1}$ adjusted NP for $100 \mathrm{~kg}$ NPSB ha- $53.7 \mathrm{~kg} \mathrm{P} \mathrm{ha}{ }^{-1}+138 \mathrm{~kg} \mathrm{~N} \mathrm{ha}^{-1}$ adjusted NP for $150 \mathrm{~kg}^{\mathrm{NPSB}} \mathrm{ha}^{-1}, 46 \mathrm{~kg} \mathrm{P} \mathrm{ha}^{-1}+128 \mathrm{~kg}$ $\mathrm{N} \mathrm{ha}^{-1}$ adjusted NP for $200 \mathrm{~kg}$ NPSB ha-1. Whereas, 146 kg N ha ${ }^{-1}+61.5 \mathrm{~kg} \mathrm{P} \mathrm{ha}^{-1}, 138 \mathrm{~kg} \mathrm{~N} \mathrm{ha}^{-1}+53.7 \mathrm{~kg} \mathrm{P} \mathrm{ha}^{-1}$ and $128 \mathrm{~kg} \mathrm{~N} \mathrm{ha}^{-1}+46 \mathrm{~kg} \mathrm{P} \mathrm{ha}^{-1}$ were added respectively to the blended fertilizer as triple super phosphate for $100 \mathrm{~kg}$ NPSB, $150 \mathrm{~kg}$ NPSB and $200 \mathrm{~kg}$ NPSB ha ${ }^{-1}$ to bring the macronutrients of blended fertilizer equal to the recommended $\mathrm{N}$ and $\mathrm{P}$ and six fertilizer treatments used were selected based on their high yield and high economic net return both in Belg and Meher seasons from the two separate experiments conducted earlier.

\section{Experimental procedures}

A month before planting, cattle manure at the rate of $7.5 \mathrm{t} \mathrm{ha}^{-1}$ and vermicompost at the rates of 5 and $7.5 \mathrm{t} \mathrm{ha}^{-1}$ were mixed in plots as per treatment 

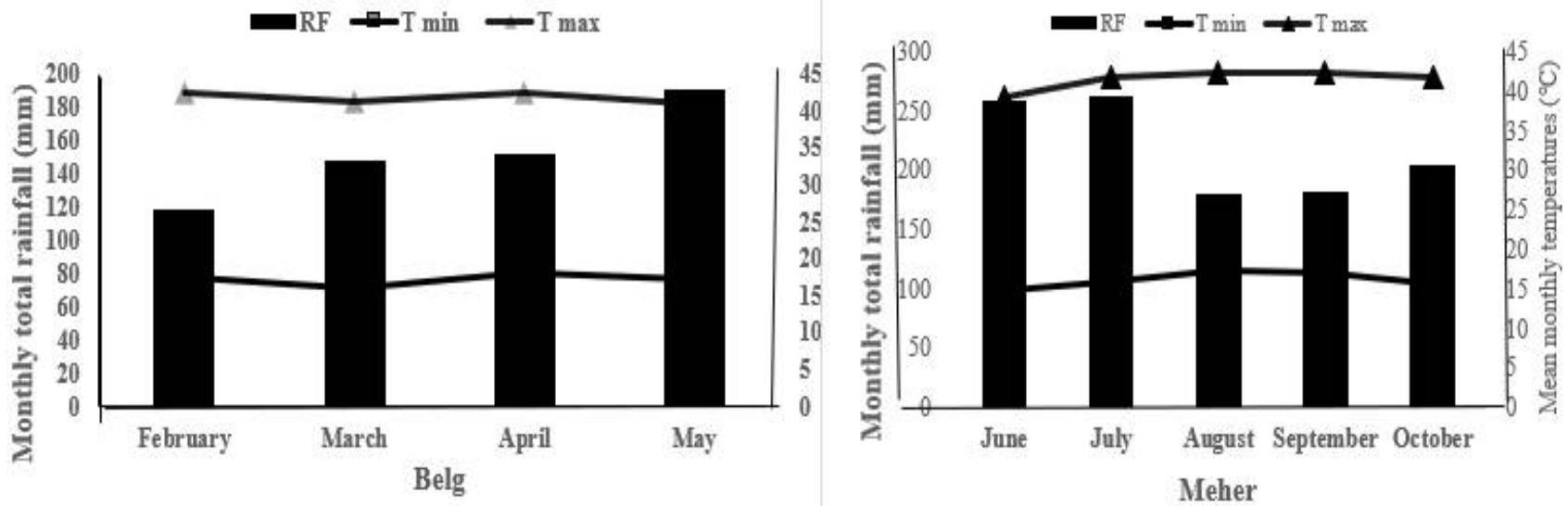

Fig. 1. Monthly mean maximum (Tmax) and minimum (Tmin) temperatures $\left({ }^{\circ} \mathrm{C}\right)$ and monthly total rainfall (mm) of the study site in Belg and Meher cropping seasons.

Table 1. Description of treatment combinations

\begin{tabular}{|c|c|}
\hline $\begin{array}{l}\text { Treat } \\
\text { ment }\end{array}$ & Description \\
\hline $\mathrm{T} 1$ & No-fertilizer (control) \\
\hline $\mathrm{T} 2$ & $165 \mathrm{~kg} \mathrm{~N} \mathrm{ha}^{-1}+60 \mathrm{~kg} \mathrm{P} \mathrm{ha}^{-1}$ \\
\hline T3 & $100 \mathrm{~kg}$ NPSB ha ${ }^{-1}+61.5 \mathrm{~kg} \mathrm{P} \mathrm{ha}^{-1}+146 \mathrm{~kg} \mathrm{~N} \mathrm{ha}^{-1}$ \\
\hline $\mathrm{T} 4$ & $150 \mathrm{~kg} \mathrm{NPSB} \mathrm{ha}^{-1}+53.7 \mathrm{~kg} \mathrm{P} \mathrm{ha}^{-1}+138 \mathrm{~kg} \mathrm{~N} \mathrm{ha}^{-1}$ \\
\hline T5 & $200 \mathrm{~kg}$ NPSB ha ${ }^{-1}+46 \mathrm{~kg} \mathrm{P} \mathrm{ha}^{-1}+128 \mathrm{~kg} \mathrm{~N} \mathrm{ha}^{-1}$ \\
\hline T6 & 124 kg N ha-1 +45 kg P ha ${ }^{-1}+5$ t Vermicompost ha ${ }^{-1}$ \\
\hline T7 & $82.5 \mathrm{~kg} \mathrm{~N} \mathrm{ha}^{-1}+30 \mathrm{~kg} \mathrm{P} \mathrm{ha}^{-1}+7.5$ t Cattle manure ha ${ }^{-1}$ \\
\hline $\mathrm{T} 8$ & $41.25 \mathrm{~kg} \mathrm{~N} \mathrm{ha}^{-1}+15 \mathrm{~kg} \mathrm{P} \mathrm{ha}^{-1}+7.5 \mathrm{t} \mathrm{Vermicompost} \mathrm{ha}^{-1}$ \\
\hline T9 & $124 \mathrm{~kg} \mathrm{~N} \mathrm{ha}^{-1}+45 \mathrm{~kg} \mathrm{P} \mathrm{ha}^{-1}+7.5$ t Cattle manure ha-1 \\
\hline $\mathrm{T} 10$ & $82.5 \mathrm{~kg} \mathrm{~N} \mathrm{ha}^{-1}+30 \mathrm{~kg} \mathrm{P} \mathrm{ha}{ }^{-1}+7.5$ t Vermicompost ha-1 \\
\hline $\mathrm{T} 11$ & $124 \mathrm{~kg} \mathrm{~N} \mathrm{ha}^{-1}+45 \mathrm{~kg} \mathrm{P} \mathrm{ha}^{-1}+7.5 . \mathrm{t}$ vermicompost ha ${ }^{-1}$ \\
\hline
\end{tabular}

requirements. Pre-sprouted potato tuber of uniform size was planted on February 02, 2020, in Belg and on June 02, 2020, in Meher season. Triple superphosphate was mixed well with the soil near the hills, while urea was side-dressed @ 25\%, 50\%, and the rest $25 \%$ at plant emergence, mid-stage (40 days after planting) and tuber initiation stage, respectively. When plants reached physiological maturity, dehaluming practice was adopted to thicken the tuber periderm. When $70 \%$ of haulms were dried harvesting was done (16).

\section{Data collection}

\section{Phenology and growth parameters}

Observations on 50\% flowering, $70 \%$ maturity, plant height, number of main stems hill-1 and dry root and shoot biomass were recorded (17).

\section{Tuber quality parameters}

\section{Tuber size distribution (\%):}

All tubers from ten randomly selected hills were categorized into small $(<39$ gm), medium (39-75 $\mathrm{gm})$, and large (>75 gm) sizes (18).

\section{Specific gravity of tubers $\left(\mathrm{g} \mathrm{cm}^{-3}\right)$ :}

Tubers amounting $5 \mathrm{~kg}$ were randomly sampled from each treatment. The selected tubers were washed, weighed in air and then reweighed by submerging them in water. Specific gravity was calculated using the following formula (19).

$$
S G=\frac{W a}{W a-W w}
$$

Where, $\mathrm{SG}=$ Specific gravity in $\mathrm{gm}^{\mathrm{cm}}{ }^{-3}$, Wa $=$ Weight in the air, Ww= Weight in water.

\section{Dry matter content of tuber}

Ten tubers representing all size categories were chopped into small-sized $1-2 \mathrm{~cm}$ cubes, mixed thoroughly and subsamples each weighing $200 \mathrm{gm}$ were taken and placed in a separate paper bag and placed in the oven until constant weight was attained. The dry weight of each subsample was recorded. The percent dry matter was calculated as follows (16):

$$
D M(\%)=\frac{\text { Dry weight of sample }}{\text { Fresh weight of sample }} \times 100
$$

\section{Statistical analysis}

Data were analyzed using SAS software program version 9.2 and homogeneity of variances was calculated (20). A separate analysis was used for the two seasons and the least significant difference (LSD 0.05 ) was employed to separate treatment means.

\section{Results and Discussion}

\section{Phenology and growth parameters of potato}

\section{Days to flowering and maturity}

The analysis of variance revealed that fertilizer management significantly $(\mathrm{p}<0.01)$ influenced days to $50 \%$ flowering and days to $70 \%$ maturity in both seasons (Table 2). Fertilizer management treatment indicated that $75 \%$ mineral NP $+7.5 \mathrm{t} \mathrm{VC} \mathrm{ha}^{-1}$ attained significantly delayed $50 \%$ flowering taking 68 days in Belg and 71 days in Meher pushing $70 \%$ maturity to 104 and 112 days, whereas the shortest days to flowering were counted to be 61 days in both seasons for the control treatment. It was observed that both processes of flowering and maturity were hastened as the rates of mineral NP and VC decreased. The possible reason might be attributed to the synergistic effects of the fertilizers in the stimulation of enhanced cell division, promoting cell growth and prolonging vegetative growth for a relatively long 
Table 2. Days to flowering (DF), days to maturity (DM), Number of main stems (NMS) per hill, Plant height (PH) (cm), Shoot dry weight (SDW gm hill ${ }^{-1}$ ) and Root dry weight (RDW gm hill ${ }^{-1}$ ) of potato as affected by the application of blended NPSB, cattle manure, vermicompost and NP fertilizer in Belg and Meher seasons

\begin{tabular}{|c|c|c|c|c|c|c|c|c|c|c|c|c|}
\hline \multirow{2}{*}{ Treatment } & \multicolumn{6}{|c|}{ Belg season } & \multicolumn{6}{|c|}{ Meher season } \\
\hline & DF & DM & NMS & PH & SDW & RDW & DF & DM & NMS & PH & SDW & RDW \\
\hline No-fertilizer (control) & $61 d$ & $95 \mathrm{c}$ & 5.26 & $56.0 \mathrm{e}$ & $35.33 f$ & $5.95 \mathrm{e}$ & $61 \mathrm{e}$ & $93 \mathrm{e}$ & 5.3 & $61.97 \mathrm{e}$ & $38.45 f$ & $6.64 d$ \\
\hline $100 \% \mathrm{NP}$ & $63 c d$ & $97 d$ & 5.00 & $56.3 \mathrm{e}$ & $36.33 f$ & $6.27 \mathrm{de}$ & $67 d$ & $107 d$ & 5.76 & $68.64 \mathrm{e}$ & $52.34 \mathrm{e}$ & $9.12 \mathrm{c}$ \\
\hline $\begin{array}{l}100 \mathrm{~kg} \text { NPSB ha }^{-1}+ \\
\text { adjusted NP }\end{array}$ & $64 \mathrm{bc}$ & $99 a b c$ & 6.60 & $61.3 \mathrm{~d}$ & 40def & 6.61cde & $68 \mathrm{~cd}$ & $108 \mathrm{~cd}$ & 5.56 & $68.79 \mathrm{e}$ & $52.34 \mathrm{e}$ & $9.35 \mathrm{c}$ \\
\hline $\begin{array}{l}150 \text { kg NPSB ha-1 + } \\
\text { adjusted NP }\end{array}$ & $64 \mathrm{bc}$ & $100 \mathrm{abc}$ & 6.40 & $62.3 \mathrm{~cd}$ & 40.3def & $7.26 \mathrm{bcde}$ & $68 \mathrm{~cd}$ & 110abcd & 5.96 & $70.97 \mathrm{bc}$ & $53.67 \mathrm{de}$ & $9.41 \mathrm{c}$ \\
\hline $\begin{array}{l}200 \mathrm{~kg}_{\text {NPSB }} \mathrm{ha}^{-1}+ \\
\text { adjusted NP }\end{array}$ & $64 \mathrm{bc}$ & $100 \mathrm{abc}$ & 6.40 & $63.3 \mathrm{bc}$ & 42.7cde & 7.73abc & $68 \mathrm{~cd}$ & $108 \mathrm{bcd}$ & 6.3 & 71.23de & $54.79 d$ & $9.31 \mathrm{c}$ \\
\hline $50 \% \mathrm{NP}+5 \mathrm{t} \mathrm{VC} \mathrm{ha}^{-1}$ & $65 \mathrm{abc}$ & $101 \mathrm{ab}$ & 5.40 & $66.0 \mathrm{abc}$ & $45.7 \mathrm{bcd}$ & $7.44 \mathrm{bcd}$ & $71 \mathrm{a}$ & $108 \mathrm{bcd}$ & 6.63 & $73.14 \mathrm{~cd}$ & $57.34 \mathrm{c}$ & $10.04 \mathrm{ab}$ \\
\hline $50 \% \mathrm{NP}+7.5$ t CM ha $^{-1}$ & $64 \mathrm{bc}$ & $101 \mathrm{ab}$ & 5.13 & $66.3 \mathrm{ab}$ & $48 \mathrm{abc}$ & $8.62 \mathrm{ab}$ & $70.7 \mathrm{ab}$ & 109abcd & 6.23 & $73.53 \mathrm{~cd}$ & $58.12 \mathrm{bc}$ & $9.49 b c$ \\
\hline $75 \% \mathrm{NP}+5 \mathrm{t} \mathrm{VC} \mathrm{ha}^{-1}$ & $66 \mathrm{ab}$ & $101 \mathrm{ab}$ & 4.93 & $66.3 \mathrm{ab}$ & $50 \mathrm{ab}$ & 7.89abc & $69 \mathrm{abc}$ & $110 \mathrm{abcd}$ & 5.9 & $73.97 \mathrm{bc}$ & $60.342 \mathrm{ab}$ & $9.48 \mathrm{bc}$ \\
\hline $75 \% \mathrm{NP}+7.5$ t CM ha $^{-1}$ & $66 a$ & $104 a$ & 5.20 & $66.3 \mathrm{ab}$ & $50.67 \mathrm{ab}$ & $8.10 \mathrm{ab}$ & $71 \mathrm{ab}$ & $111 \mathrm{abc}$ & 5.7 & $76.36 \mathrm{ab}$ & $60.34 \mathrm{ab}$ & $9.56 \mathrm{bc}$ \\
\hline $50 \% \mathrm{NP}+7.5 \mathrm{t} \mathrm{VC} \mathrm{ha}^{-1}$ & $67 a$ & $104 a$ & 5.06 & $66.6 \mathrm{ab}$ & $52.33 a$ & $8.62 \mathrm{ab}$ & $71 \mathrm{ab}$ & $111 \mathrm{ab}$ & 6.23 & $77.60 \mathrm{a}$ & $61.01 \mathrm{a}$ & $10.04 \mathrm{ab}$ \\
\hline $75 \% \mathrm{NP}+7.5 \mathrm{t} \mathrm{VC} \mathrm{ha}^{-1}$ & $68 a$ & $104 a$ & 5.20 & $68.3 a$ & $53.66 \mathrm{a}$ & $8.94 a$ & $71 \mathrm{a}$ & $112 \mathrm{a}$ & 4.9 & $78.97 a$ & $62.01 \mathrm{a}$ & $10.22 \mathrm{a}$ \\
\hline LSD (5\%) & 2.21 & 5.31 & NS & 2.13 & 7.312 & 1.370 & 2.464 & 3.485 & NS & 2.628 & 2.377 & 2.09 \\
\hline Significance & $* *$ & $*$ & NS & $* *$ & $* *$ & $* *$ & $* *$ & $* *$ & NS & $* *$ & $* *$ & $* *$ \\
\hline CV (\%) & 2.00 & 3.11 & 19 & 3.65 & 9.54 & 10.74 & 2.12 & 1.90 & 16.53 & 2.13 & 2.51 & 3.86 \\
\hline
\end{tabular}

Means followed by the same letter within a column are non-significant $(\mathrm{p}>0.05),{ }^{*}$ denotes significantly(p<0.05) different, ${ }^{* *}$ denotes significant at $1 \%$ level of probability, NS= Non-significant, VC= Vermicompost, $C M=$ Cattle manure, $146 \mathrm{~kg} \mathrm{~N} \mathrm{ha}^{-1}+61.5 \mathrm{~kg} \mathrm{Pha}^{-1}$ adjusted NP for $100 \mathrm{~kg} \mathrm{NPSB}$ ha' $138 \mathrm{~kg} \mathrm{~N} \mathrm{ha}^{-1}+53.7 \mathrm{~kg} \mathrm{Pha}^{-1}$ adjusted NP for $150 \mathrm{~kg} \mathrm{NPSB} \mathrm{ha}^{-1}, 128 \mathrm{~kg} \mathrm{~N} \mathrm{ha}^{-1}+46 \mathrm{~kg} \mathrm{P} \mathrm{ha}^{-1}$ adjusted NP for $200 \mathrm{~kg} \mathrm{NPSB} \mathrm{ha}^{-1}$.

period owing to sufficient supply of NP from the mineral fertilizers as well as organic carbon and possibly other mineral nutrients including micronutrients from the $\mathrm{VC}$ and $\mathrm{CM}$. The prolonged days required by plants to reach $50 \%$ flowering in response to increasing rates of nitrogen and phosphorus might also contribute to better root development and increased uptake of macro-and micronutrients, which lead to enhanced vegetative growth (21).

\section{Plant height}

The analysis of variance revealed that fertilizer management treatment highly significantly $(p<0.01)$ affected the potato plant height in both seasons. However, these treatments did not significantly influence the number of stems hill-1 in both seasons (Table 2). The highest plant heights of $68.33 \mathrm{~cm}$ in Belg and $78.97 \mathrm{~cm}$ in Meher season were obtained at the combined application of $75 \%$ of recommended NP with $7.5 \mathrm{t} \mathrm{VC} \mathrm{ha}{ }^{-1}$ which was statistically not different from the heights obtained in all treatments containing organic manure.

In contrast, no-fertilizer treatment (control) recorded the smallest plant height $(56 \mathrm{~cm})$ in Belg and $61.97 \mathrm{~cm}$ in Meher, which are statistically the same as those of $100 \%$ NP in Belg and 100\% NP, $100 \mathrm{~kg}$ NPSB ha $^{-1}$ in Meher. The highest plant height of potato (69.33 and $78.67 \mathrm{~cm}$ ) in Belg and Meher seasons, respectively obtained from the combined application of 7.5 t CM ha-1 with $75 \%$ of NP as compared to the nofertilizer treatment (control) $(55.96 \mathrm{~cm}$ to $69.33 \mathrm{~cm}$ ) in Belg and Meher seasons (22). Similarly, it has been demonstrated that the combined use of $3 \mathrm{t} \mathrm{ha}^{-1}$ vermicompost + Panchagvaya spray (3\% at 30, 60 and 75 DAS) + Liquid manure (2000 l ha-1) + Jeevamruta
(2000 $\mathrm{l} \mathrm{ha}^{-1}$ ) caused a taller plants $(26.8 \mathrm{~cm}$ ) compared to the application of NPK alone or no-application of NPK (23).

\section{Biomass yield}

\section{Shoot dry weight}

The results indicated that the dry biomass yield of aboveground parts were influenced $(p<0.01)$ by fertilizer management in both seasons (Table 2). The maximum dry weights hill-1 ${ }^{-1} 53.66 \mathrm{gm}^{-1}$ Belg and $62.01 \mathrm{gm} \mathrm{hill}^{-1}$ in Meher were recorded in the combined application of 75\% mineral NP $+7.5 \mathrm{t} \mathrm{ha}^{-1}$ vermicompost. The use of NP and vermicompost together resulted in better dry matter yield than the use of mineral fertilizer alone probably because of more nutrients made available from the vermicompost as well as the improved physicochemical and microbial conditions of the soil. This situation possibly resulted in increased leaf expansion and increased leaf number that led to increased concentration of chlorophyll in the leaves, thereby enhancing the rate of photosynthesis, resulting in a high rate of dry matter accumulation in the aboveground biomass. The highest shoot dry weight (59.33 gm hill-1 and $56.67 \mathrm{gm} \mathrm{hill}^{-1}$ ) were recorded at the highest rate of $7.5 \mathrm{CM} \mathrm{tha}^{-1}+75 \%$ of NP in Belg and Meher seasons respectively (22). In potato crop, maximum shoot dry matter $\left(68 \mathrm{gm} \mathrm{hill}^{-1}\right)$ with integrated use of $120 \mathrm{~kg} \mathrm{~N} \mathrm{ha}^{-1}+10 \mathrm{t} \mathrm{ha}^{-1}$ vermicompost was obtained as compared to the treatment that did not receive any of the fertilizer treatment combination (55 gm hill ${ }^{-1}$ ) (24). The present results agree with an earlier work (25) who demonstrated that the maximum amount of shoot dry matter could be obtained by the combined application of compost and chemical fertilizer. 


\section{Root dry weight}

Fertilizer treatment significantly $(p<0.05)$ influenced the root dry weight both in the Belg and Meher seasons (Table 2). Accordingly, 75\% NP + $7.5 \mathrm{t} \mathrm{VC} \mathrm{ha}^{-1}$ had resulted in the highest root dry weight of $8.94 \mathrm{gm}$ in Belg and $10.22 \mathrm{gm}$ in Meher season. However, the lowest root dry weights of $5.95 \mathrm{gm}$ in Belg and 6.64 $\mathrm{gm}$ in Meher were obtained at no-fertilizer treatment (control). As mentioned earlier, this might be due to vermicompost addition which improves soil physicochemical and biological properties, thereby increasing the availability of micro-and macronutrients in soil and enhance the uptake by plant tissues as there is a positive relation of the concentration of nutrients in the plant with root and shoot dry biomass of potato (22). Similar result was recorded earlier (26) who reported the maximum dry weight $\left(87.07 \mathrm{gm} \mathrm{plant}^{-1}\right)$ when $75 \% \mathrm{NP}+2 \mathrm{t} \mathrm{ha}^{-1} \mathrm{VC}+$ $20 \mathrm{~kg} \mathrm{ha}^{-1}$ sulfur $+20 \mathrm{~kg} \mathrm{ha}^{-1}$ zinc sulfate + Azotobacter (seed treatment) were administered which was superior to $100 \% \mathrm{NP}$ and no-fertilizer treatment (control). Accordingly, the application of $7.5 \mathrm{t} \mathrm{CM} \mathrm{ha}^{-1}$ in combination with $75 \%$ of NP gave the highest root dry weight of $9.34 \mathrm{gm} \mathrm{hill}^{-1}$ in Belg and $9.59 \mathrm{gm} \mathrm{hill}^{-1}$ in Meher (22).

\section{Tuber quality parameters}

\section{Potato tuber size category}

There was a significant difference $(p<0.05)$ between the medium and small-sized tuber categories due to fertilizer management treatment in both seasons, but the effect was nonsignificant for large-sized tubers (Table 3). The highest proportions of medium size tuber category of $47.7 \%$ in Belg and $68 \%$ in Meher season were obtained when $7.5 \mathrm{t}$ vermicompost ha ${ }^{-1}$ and $75 \%$ of the recommended rate of NP were added together. On the other hand, the lowest proportions of medium size tuber category (28\%) in Belg and
$46.19 \%$ in Meher season were from control treatment. It has been reported that using $2.0 \mathrm{t} \mathrm{ha}^{-1}$ wood ash +5.0 t FYM ha- ${ }^{-1}+5.0$ t CM ha $^{-1}+100 \%$ NP $\left(111 \mathrm{~kg} \mathrm{~N}+40 \mathrm{~kg} \mathrm{P} \mathrm{ha}^{-1}\right)$ yielded the greatest medium size tuber weight of $62.03 \%$ and the lowest $(37.10 \%)$ in control treatment. Similarly, fertilizer management had a highly significantly $(\mathrm{p}<0.01)$ effect on the proportion of small size tuber categories in both seasons. The proportion of small tuber size category ranged from $48.57 \%$ and $26.99 \%$, which was registered from the use of $7.5 \mathrm{t} \mathrm{VC} \mathrm{ha}^{-1}+75 \%$ mineral NP. However, a higher percentage of small-sized tuber category of $63.52 \%$ and $48.57 \%$ were obtained from the control treatment (control) in Belg and Meher seasons, respectively. However, there was no significant difference among large-sized tubers in both seasons (27).

The significant decrease in small size tuber was due to vermicompost and mineral NP application which may have brought an improvement in soil structure that probably helped use nutrients efficiently resulting in an increase in tuber size than the number. Besides, $\mathrm{N}$ and $\mathrm{P}$ in the soil and vermicompost might have caused the increase in size of the tuber, reflecting the improved allocation of photosynthate to the tubers as a result of enhanced soil physical and chemical properties. It has been found that the application of vermicompost at $10 \mathrm{t}$ $\mathrm{ha}^{-1}$ together with mineral fertilizers to complete the rest of the $100 \%$ of the recommended fertilizer dose of $150 \mathrm{~N}, 75 \mathrm{P}, 75 \mathrm{~K}$ (CFNP) + microbial consortium reduced the number of small size tubers from $13.4 \%$ in control treatment to $8.8 \%$ in the test treatment (28).

\section{Specific gravity (SG) of tubers}

A highly significant $(p<0.01)$ effect of fertilizers was observed on the specific gravity and dry matter content of potato tubers in both seasons (Table 4). Accordingly, the highest specific gravity of $1.107 \mathrm{gm}$

Table 3. Percentage of large size tuber (LST) ( $>75$ gm), medium size tuber (MST) (75-39 gm) and small size tubers (SST) (<39 gm) of potato as affected by the integrated use of NPSB, cattle manure, vermicompost and NP fertilizers.

\begin{tabular}{|c|c|c|c|c|c|c|}
\hline \multirow{2}{*}{ Treatment } & \multicolumn{3}{|c|}{ Belg } & \multicolumn{3}{|c|}{ Meher } \\
\hline & LST & MST & SST & LST & MST & SST \\
\hline No-fertilizer (control) & 8.48 & $28.00 \mathrm{~d}$ & $63.52 \mathrm{a}$ & 9.95 & $46.19 \mathrm{~g}$ & $43.86 a$ \\
\hline $100 \% \mathrm{NP}$ & 9.50 & $28.98 d$ & $61.52 \mathrm{a}$ & 15.45 & $50.44 \mathrm{fg}$ & $34.11 \mathrm{~b}$ \\
\hline 100 kg NPSB ha-1 + adjusted NP & 10.02 & $30.13 d$ & $59.85 \mathrm{ab}$ & 12.14 & $54.88 \mathrm{ef}$ & $32.98 \mathrm{bc}$ \\
\hline 150 kg NPSB ha-1 + adjusted NP & 12.49 & $30.31 d$ & $57.20 \mathrm{bc}$ & 11.01 & 55.59def & $33.40 \mathrm{bc}$ \\
\hline 200 kg NPSB ha-1 + adjusted NP & 14.04 & $30.65 \mathrm{~cd}$ & $55.31 \mathrm{~cd}$ & 10.43 & $56.20 \mathrm{cdef}$ & $33.37 \mathrm{bc}$ \\
\hline $50 \% \mathrm{NP}+5 \mathrm{t} \mathrm{VC} \mathrm{ha}^{-1}$ & 12.10 & $34.25 \mathrm{~cd}$ & $53.65 \mathrm{cde}$ & 9.36 & $59.69 \mathrm{bcde}$ & $30.95 \mathrm{bcd}$ \\
\hline $50 \% \mathrm{NP}+7.5 \mathrm{t} \mathrm{CM} \mathrm{ha}^{-1}$ & 11.46 & $36.04 \mathrm{~cd}$ & $52.50 \mathrm{def}$ & 10.74 & $61.47 \mathrm{bcd}$ & $27.785 d$ \\
\hline $75 \% \mathrm{NP}+5 \mathrm{t} \mathrm{VC} \mathrm{ha}{ }^{-1}$ & 9.80 & $38.66 \mathrm{bc}$ & $51.54 \mathrm{def}$ & 8.71 & $61.90 \mathrm{bc}$ & $29.39 \mathrm{~cd}$ \\
\hline $75 \% \mathrm{NP}+7.5 \mathrm{t} \mathrm{CM} \mathrm{ha}^{-1}$ & 4.25 & 45.19ab & $50.56 \mathrm{ef}$ & 10.42 & $62.60 \mathrm{ab}$ & $26.98 \mathrm{~d}$ \\
\hline $50 \% \mathrm{NP}+7.5 \mathrm{t} \mathrm{VC} \mathrm{ha}^{-1}$ & 5.05 & $45.38 \mathrm{ab}$ & $49.57 \mathrm{ef}$ & 6.53 & $65.69 \mathrm{ab}$ & $27.78 \mathrm{~d}$ \\
\hline $75 \% \mathrm{NP}+7.5 \mathrm{t} \mathrm{VC} \mathrm{ha}^{-1}$ & 3.76 & $47.67 a$ & $48.57 \mathrm{f}$ & 5.01 & $68.00 \mathrm{a}$ & $26.99 d$ \\
\hline LSD (5\%) & NS & 8.105 & 4.297 & NS & 6.062 & 4.439 \\
\hline Significance & NS & $* *$ & $* *$ & NS & $* *$ & $* *$ \\
\hline CV (\%) & 35.17 & 13.22 & 4.6 & 41.92 & 6.09 & 8.13 \\
\hline
\end{tabular}

Means followed by the same letter within a column are non-significant $(\mathrm{p}>0.05)$ and ${ }^{* *}$ denotes significant difference at $1 \%$ level of probability, NS=Non-significant, $\mathrm{VC}=$ Vermicompost, $\mathrm{CM}=$ Cattle manure, $146 \mathrm{~kg} \mathrm{~N} \mathrm{ha}^{-1}+61.5 \mathrm{~kg} \mathrm{Pha}^{-1}$ adjusted NP for $100 \mathrm{~kg}$ NPSB ha-1 138 $\mathrm{kg} \mathrm{N} \mathrm{ha}{ }^{-1}+53.7 \mathrm{~kg} \mathrm{Pha}^{-1}$ adjusted NP for $150 \mathrm{~kg} \mathrm{NPSB} \mathrm{ha}^{-1}, 128 \mathrm{~kg} \mathrm{~N} \mathrm{ha}^{-1}+46 \mathrm{~kg} \mathrm{P} \mathrm{ha}^{-1}$ adjusted NP for $200 \mathrm{~kg}^{\mathrm{N} P S B} \mathrm{ha}^{-1}$. 
$\mathrm{cm}^{-3}$ in Belg and $1.11 \mathrm{gm} \mathrm{cm}^{-3}$ in Meher were observed with the use of $7.5 \mathrm{t} \mathrm{VC} \mathrm{ha-1}+75 \%$ of the recommended rate of mineral NP, the lowest values of specific gravity $\left(1.082 \mathrm{gm} \mathrm{cm}^{-3}\right)$ in Belg and 1.084 $\mathrm{gm} \mathrm{cm}^{-3}$ in Meher were obtained in the no-fertilizer treatment. The increment in specific gravity might be associated with the vermicompost and mineral $\mathrm{N}$ that enhance the availability of nutrients to plant that ultimately increases the biomass. In line with this result, it was also reported that the increased nitrogen application from 0 to $56 \mathrm{~kg} \mathrm{ha}^{-1}$ significantly enhanced the specific gravity of potato tubers, which ranged from 1.05 to $1.06 \mathrm{gm} \mathrm{cm}^{-3}$ (29). It has also been demonstrated that increasing vermicompost and mineral fertilizer tend to increase the highest specific gravity of $1.1 \mathrm{gm} \mathrm{cm}^{-3}$ in Belg and $1.107 \mathrm{gm} \mathrm{cm}^{-3}$ in Meher in the combined application of 75\% of NP +7.5 t ha ${ }^{-1}$ VC (22).

\section{Dry matter content (DMC) of tubers}

Fertilizer management indicated that the highest dry matter contents of $26.71 \%$ in Belg and $25.9 \%$ in Meher were recorded in the treatment having $7.5 \mathrm{t}$ VC ha ${ }^{-1}+75 \%$ NP. While, the lowest $21.28 \mathrm{gm}$ in Belg and $21 \mathrm{gm}$ in Meher season were obtained in control treatment (Table 4). The highest tuber dry matter content of $24.14 \%$ in Belg and $25.78 \%$ in Meher were recorded at the combination of $7.5 \mathrm{t} \mathrm{ha}^{-1} \mathrm{VC}+75 \%$ mineral NP. The lowest dry matter content of $20.21 \%$ in Belg and $20.54 \%$ in Meher were recorded for the control (22). The significant increase in dry matter content was due to vermicompost and mineral NP application which may have brought an improvement in soil structure that probably helped to use nutrients efficiently. Besides, $\mathrm{N}$ and $\mathrm{P}$ in the soil and vermicompost might have caused the increase in size of the tuber, reflecting the improved allocation of photosynthate to the tubers.

\section{Total soluble solids (TSS)}

The effects of fertilizer management were significant $(p<0.05)$ for total soluble solids, starch content and crude protein content of tubers (Table 5). The highest total soluble solids of $8.43^{\circ} \mathrm{Brix}$ in Belg and $9.54^{\circ} \mathrm{Brix}$ in Meher season were observed at $75 \% \mathrm{NP}+7.5$. t VC ha $^{-1}$ which were statistically the same as those obtained from the treatments consisting of $\mathrm{VC}$ and $\mathrm{CM}$ in Belg apart from those such as $50 \% \mathrm{NP}+7.5 \mathrm{t} \mathrm{VC}$ $\mathrm{ha}^{-1}, 75 \% \mathrm{NP}+7.5 \mathrm{t} \mathrm{CM} \mathrm{ha}^{-1}$ in Meher. The content of total soluble solids (5.78 ${ }^{\circ} \mathrm{Brix}$ ) in Belg and $4.52{ }^{\circ} \mathrm{Brix}$ in Meher under control treatment with rest of the treatments statistically the same. The combined organic and urea treatment at the rates of $309 \mathrm{~kg} \mathrm{ha}^{-1}$ and $68.5 \mathrm{~kg} \mathrm{ha}^{-1}$ respectively, resulted in better accumulation of total soluble solids in carrot at the time of harvest (29).

\section{Starch content}

Furthermore, the effect of fertilizer indicated that the highest starch content of 19.26\% in Belg and 19.75\% in Meher were obtained from the application of $7.5 \mathrm{t}$ VC ha-1 $+75 \%$ recommended rate of mineral NP (124 $\mathrm{kg} \mathrm{N} \mathrm{ha}{ }^{-1}$ and $45 \mathrm{~kg} \mathrm{P} \mathrm{ha}^{-1}$ ), while the lowest starch contents of 14.32\% in Belg and 14.72\% in Meher were obtained in control treatment (Table 5). The increase in starch content with the increase in nutrient dosage is attributed to the role of vermicompost in plant nutrition. The effect of mineral fertilizers and vermicompost on the starch content of the tubers has been studied and reported that the application of 82 $\mathrm{kg} \mathrm{N} \mathrm{ha}{ }^{-1}+29 \mathrm{~kg} \mathrm{P} \mathrm{ha}^{-1}$ and 7.5 t vermicompost ha ${ }^{-1}$ increased the starch content by $12 \%$ as compared to the application of any fertilizer (30).

\section{Crude protein content}

As for the crude protein content, the highest values of $13.17 \%$ in Belg and $19.74 \%$ in Meher season were obtained by the application of $200 \mathrm{~kg}$ blended NPSB $\mathrm{ha}^{-1}+128 \mathrm{~kg} \mathrm{~N} \mathrm{ha}^{-1}$ while, the lowest crude protein contents of $7.29 \%$ in Belg and $8.32 \%$ in Meher were obtained in treatment receiving none of the fertilizers (Table 5). The increase of tuber nitrogen with increasing NPSB application rate observed in the present study is probably due to sulfur and boron which improve the accumulation and partitioning of nitrogen in tubers and sulfur is a component of protein enzymes involved in chlorophyll synthesis. Similarly, it was reported that using potassium sulfate for sulphur fertilization at $100 \mathrm{~kg}$ increased crude protein

Table 4. Specific gravity (SG g cm${ }^{-3}$ ) and dry matter content (DMC\%) of potato tubers as affected by the use of blended NPSB, cattle manure, vermicompost and NP fertilizers.

\begin{tabular}{lrrrr}
\hline \multirow{2}{*}{ Treatment } & \multicolumn{2}{c}{ Belg season } & \multicolumn{2}{c}{ Meher season } \\
\cline { 2 - 5 } & SG & DMC & SG & DMC \\
\hline No-fertilizer (control) & $1.0826 \mathrm{~g}$ & $21.28 \mathrm{~g}$ & $1.084 \mathrm{~h}$ & $21.00 \mathrm{~g}$ \\
\hline $100 \% \mathrm{NP}$ & $0863 \mathrm{fg}$ & $22.10 \mathrm{fg}$ & $1.086 \mathrm{gh}$ & $21.27 \mathrm{fg}$ \\
\hline $100 \mathrm{~kg} \mathrm{NPSB} \mathrm{ha}^{-1}+$ adjusted NP & $1.089 \mathrm{ef}$ & $22.70 \mathrm{ef}$ & $1.087 \mathrm{fgh}$ & $21.42 \mathrm{efg}$ \\
\hline $150 \mathrm{~kg} \mathrm{NPSB} \mathrm{ha}^{-1}+$ adjusted NP & $1.090 \mathrm{ef}$ & $22.92 \mathrm{de}$ & $1.089 \mathrm{efgh}$ & $21.77 \mathrm{defg}$ \\
\hline $200 \mathrm{~kg} \mathrm{NPSB} \mathrm{ha}^{-1}+$ adjusted NP & $1.091 \mathrm{de}$ & $23.19 \mathrm{de}$ & $1.089 \mathrm{efg}$ & $21.88 \mathrm{def}$ \\
\hline $50 \% \mathrm{NP}+5 \mathrm{t} \mathrm{VC} \mathrm{ha}^{-1}$ & $1.093 \mathrm{de}$ & $23.54 \mathrm{de}$ & $1.092 \mathrm{def}$ & $22.12 \mathrm{cde}$ \\
\hline $50 \% \mathrm{~N} \mathrm{P}+7.5 \mathrm{t} \mathrm{CM} \mathrm{ha}^{-1}$ & $1.095 \mathrm{de}$ & $24.11 \mathrm{~cd}$ & $1.0924 \mathrm{cde}$ & $22.35 \mathrm{~cd}$ \\
\hline $75 \% \mathrm{NP}+5 \mathrm{VC} \mathrm{ha}^{-1}$ & $1.096 \mathrm{~cd}$ & $24.15 \mathrm{~cd}$ & $1.094 \mathrm{de}$ & $22.54 \mathrm{~cd}$ \\
\hline $75 \% \mathrm{NP}+7.5 \mathrm{t} \mathrm{CM} \mathrm{ha}^{-1}$ & $1.098 \mathrm{bc}$ & $24.54 \mathrm{bc}$ & $1.096 \mathrm{bc}$ & $22.92 \mathrm{c}$ \\
\hline $50 \% \mathrm{NP}+7.5 \mathrm{t} \mathrm{VC} \mathrm{ha}^{-1}$ & $1.101 \mathrm{~b}$ & $25.41 \mathrm{~b}$ & $1.099 \mathrm{~b}$ & $24.03 \mathrm{~b}$ \\
\hline $75 \% \mathrm{NP}+7.5 \mathrm{t} \mathrm{VC} \mathrm{ha}^{-1}$ & $1.107 \mathrm{a}$ & $26.71 \mathrm{a}$ & $1.110 \mathrm{a}$ & $25.90 \mathrm{a}$ \\
\hline LSD $5 \%)$ & 0.005 & 0.98 & 0.004 & 0.821 \\
\hline Significance & $* *$ & $* *$ & $* *$ & $*$ \\
\hline CV (\%) & 0.24 & 2.43 & 0.23 & 2.14 \\
\hline
\end{tabular}

Means followed by the different letter within a column are significantly different from each other; ** denotes difference at $1 \%$ level of probability, VC= Vermicompost, CM= Cattle manure, $146 \mathrm{~kg} \mathrm{~N} \mathrm{ha}^{-1}+61.5 \mathrm{~kg} \mathrm{Pha}^{-1}$ adjusted NP for $100 \mathrm{~kg} \mathrm{NPSB} \mathrm{ha}^{-1}, 138 \mathrm{~kg} \mathrm{~N} \mathrm{ha}^{-1}+53.7 \mathrm{~kg} \mathrm{P}$ $\mathrm{ha}^{-1}$ adjusted NP for $150 \mathrm{~kg}_{\text {NPSB ha }}{ }^{-1}, 128 \mathrm{~kg} \mathrm{~N} \mathrm{ha}^{-1}+46 \mathrm{~kg} \mathrm{P} \mathrm{ha}^{-1}$ adjusted NP for $200 \mathrm{~kg} \mathrm{NPSB} \mathrm{ha}^{-1}$. 
Table 5. Total soluble solids(TSS ${ }^{\circ}$ Brix), starch content (SC\%) and crude protein content (CP\%) of potato tubers as affected by blended NPSB, cattle manure, vermicompost and NP fertilizers.

\begin{tabular}{|c|c|c|c|c|c|c|}
\hline \multirow{2}{*}{ Treatment } & \multicolumn{3}{|c|}{ Belg season } & \multicolumn{3}{|c|}{ Meher season } \\
\hline & TSS & SC & $\mathbf{C P}$ & TSS & SC & $\mathbf{C P}$ \\
\hline No-fertilizer (control) & $5.78 \mathrm{c}$ & $14.32 \mathrm{~g}$ & $7.29 \mathrm{c}$ & $4.52 \mathrm{f}$ & $14.72 \mathrm{~h}$ & $8.32 \mathrm{~h}$ \\
\hline $100 \% \mathrm{NP}$ & $5.78 \mathrm{c}$ & $15.06 \mathrm{fg}$ & $7.75 \mathrm{bc}$ & 5.21ef & 15.09gh & 10.04gh \\
\hline $150 \mathrm{~kg} \mathrm{NPSB} \mathrm{ha}^{-1}+$ adjusted NP & $6.04 \mathrm{bc}$ & 15.81ef & $13.08 \mathrm{a}$ & 5.93de & 15.55efgh & $17.01 \mathrm{~b}$ \\
\hline $200 \mathrm{~kg} \mathrm{NPSB} \mathrm{ha}^{-1}+$ adjusted NP & $6.45 \mathrm{bc}$ & $16.05 \mathrm{de}$ & $13.17 \mathrm{a}$ & $6.26 \mathrm{de}$ & 15.60efg & $19.74 a$ \\
\hline $50 \% \mathrm{NP}+5 \mathrm{t} \mathrm{VC} \mathrm{ha}^{-1}$ & $6.80 \mathrm{abc}$ & $16.37 \mathrm{de}$ & $12.86 \mathrm{a}$ & 6.33de & 16.15def & $11.30 \mathrm{fg}$ \\
\hline $50 \% \mathrm{NP}+7.5$ t CM ha $^{-1}$ & 7.23abc & $16 c .89 c d$ & $11.95 a$ & $6.93 \mathrm{~cd}$ & $16.29 \mathrm{cde}$ & 13.07def \\
\hline $75 \% \mathrm{NP}+5 \mathrm{t} \mathrm{VC} \mathrm{ha}^{-1}$ & 7.59abc & $16.93 \mathrm{~cd}$ & $10.67 \mathrm{ab}$ & $7.79 \mathrm{bc}$ & $16.61 \mathrm{~cd}$ & $11.77 \mathrm{fg}$ \\
\hline $75 \% \mathrm{NP}+7.5$ t CM ha $^{-1}$ & 7.84abc & $17.2 \mathrm{bc}$ & $10.51 \mathrm{abc}$ & $8.22 \mathrm{abc}$ & $17.08 \mathrm{bc}$ & $12.34 \mathrm{ef}$ \\
\hline $50 \% \mathrm{NP}+7.5 \mathrm{t} \mathrm{VC} \mathrm{ha}^{-1}$ & $8.12 \mathrm{ab}$ & $18.08 \mathrm{~b}$ & $11.148 \mathrm{a}$ & $8.61 \mathrm{ab}$ & $17.64 \mathrm{~b}$ & $14.36 \mathrm{cde}$ \\
\hline $75 \% \mathrm{NP}+7.5 \mathrm{t} \mathrm{VC} \mathrm{ha}^{-1}$ & $8.43 a$ & $19.26 \mathrm{a}$ & $11.33 a$ & $9.54 a$ & $19.75 a$ & $14.43 \mathrm{~cd}$ \\
\hline LSD (5\%) & 2.332 & 0.894 & 3.34 & 1.35 & 0.872 & 2.062 \\
\hline Significance & $* *$ & $* *$ & $* *$ & $* *$ & $* *$ & $* *$ \\
\hline CV (\%) & 19.84 & 3.18 & 17.58 & 11.66 & 3.13 & 9.02 \\
\hline
\end{tabular}

Means followed by the same letter within a column are non-significant (p > 0.05); ${ }^{* *}$ denotes difference at $1 \%$ level of probability, VC= Vermicompost, $\mathrm{CM}=$ Cattle manure, $146 \mathrm{~kg} \mathrm{~N} \mathrm{ha}^{-1}+61.5 \mathrm{~kg} \mathrm{Pha}^{-1}$ adjusted NP for $100 \mathrm{~kg} \mathrm{NPSB} \mathrm{ha}^{-1}, 138 \mathrm{~kg} \mathrm{~N} \mathrm{ha}^{-1}+53.7 \mathrm{~kg} \mathrm{P}^{-1}$ adjusted NP for $150 \mathrm{~kg}^{\mathrm{NPSB} \mathrm{ha}}{ }^{-1}, 128 \mathrm{~kg} \mathrm{~N} \mathrm{ha}^{-1}+46 \mathrm{~kg} \mathrm{P} \mathrm{ha}^{-1}$ adjusted NP for $200 \mathrm{~kg} \mathrm{NPSB} \mathrm{ha}^{-1}$.

content from 12.2 to $20.6 \%$ (31). In addition, it was also reported that the fertilization of sulphur raised up to $45 \mathrm{~kg} \mathrm{ha}^{-1}$ increased the crude protein content from $4.09 \%$ in the year 2002 to $4.82 \%$ in the year 2003 (32).

\section{Conclusion}

The present study indicated that the growth, biomass, and nutritional quality of potato as well in both seasons of Belg and Meher were significantly affected by the fertilizer management treatments. Among the various treatments, the combined use of $7.5 \mathrm{t} \mathrm{VC} \mathrm{ha-1}$ and $75 \%$ of the recommended rate of inorganic NP fertilizers (124 $\mathrm{kg} \mathrm{N} \mathrm{ha}{ }^{-1}$ and $45 \mathrm{~kg} \mathrm{P} \mathrm{ha}^{-1}$ ) gave the highest biomass yield of potato in both seasons. On the other hand, the highest crude protein contents among the potato quality parameters were recorded at the application of $200 \mathrm{~kg} \mathrm{ha}^{-1}$ of blended NPSB, whereas total soluble solid sand starch contents were highest at the application of $7.5 \mathrm{t} \mathrm{VC} \mathrm{ha-1}+75 \%$ of the recommended rate of $\mathrm{NP}\left(124 \mathrm{~kg} \mathrm{~N} \mathrm{ha}^{-1}+45 \mathrm{~kg}\right.$ $\left.\mathrm{P} \mathrm{ha}^{-1}\right)$. Thus, the treatment $7.5 \mathrm{t} \mathrm{VC} \mathrm{ha} \mathrm{ha}^{-1}+75 \%$ of the recommended rate of NP $\left(124 \mathrm{~kg} \mathrm{~N} \mathrm{ha}^{-1}+45 \mathrm{~kg}\right.$ $\mathrm{P} \mathrm{ha}^{-1}$ ) gave the best results with respect to enhancing biomass and nutritional quality of potatoes in the study area than the use of mineral fertilizers alone. Since the present studies have been attempted only for two seasons and organic fertilizers such as $\mathrm{CM}$ and VC have long-term residual effects, there is a need to conduct a longterm study using multiple combination ratios of NPSB fertilizer with vermicompost and cattle manure on different soils in different agro-climatic zones to come up with conclusive recommendations.

\section{Authors' contributions}

Author IZ designed and executed the experiments and drafted the manuscript. SS revised the manuscript critically and made it fit for publishing. HK coordinated the research with IZ and performed the statistical analyses. All authors read and approved the final manuscript.

\section{Conflict of interests}

The authors declare that they have no conflicts of interest.

\section{References}

1. FAO (Food and Agricultural Organization). International year of potato [Internet]. Rome: The Organization; 2008 [cited 2008 June 25]. Available from http://www.fao.org/potato-2008/en/potato/index.html

2. Haynes KG, Yencho GC, Clough M, Henninger ME, Sterrett SB. Genetic variation for potato tuber micronutrient content and implications for biofortification of potatoes to reduce micronutrient malnutrition. Am J Potato Res. 2012;89:192-98. https://doi.org/10.1007/s12230-012-9242-7

3. Ethiopia. Central Statistical Agency of Ethiopia. Agricultural sample survey report on area and production (private peasant holdings Meher season. Statistical Bulletin; 2017.

4. Haverkort AJ, Koesveld MJ, van Schepers HTAM, Wijnands JHM, Wustman R, Zhang XY. Potato prospects for Ethiopia: on the road to value addition. Lelystad: PPO-AGV; 2012.

5. Merkeb G, Jima N. 2016. Integrating the formal and informal maize seed supply systems to improve farmers' access to improved cultivars in Manna and Bedele woreda, south-west Ethiopia. In: Berhanu Kuma, Wondimu Tegegne, editors. Supporting national development through research 2016 Proceedings of the 5th Annual National Research Workshop of Wolaita Sodo University; 2016 May 12-13; Ethiopia.

6. Zhu J, Li M, Whelan M, Phosphorus activators contribute to legacy phosphorus availability in agricultural soils: A review.

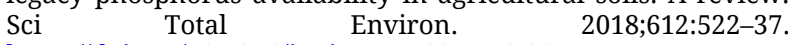
https://doi.org/10.1016/j.scitotenv.2017.08.095

7. Dhadge Y. Effect of foliar application of micronutrients and NAA on growth and yield of green gram (Vigna radiata L. Wilczek). Parbhani: Parbhani Vasantrao Naik Marathwada Krishi Vidyapeeth; 2018.

8. Sharma DK, Kushwah SS, Nema PK, Rathore SS. Effect of sulfur on yield and quality of potato (Solanum tuberosum L.). Int J Agric Res. https://doi.org/10.3923/ijar.2011.143.148

2011;6(2):143-48

9. Woubshet Demissie, Selamyihun Kidanu, Tolera Abera, Cherukuri Raghavaiah. Effects of lime, blended fertilizer (NPSB) and compost on yield and yield attributes of barley 
(Hordium vulgare L.) on acid soils of Wolmera district, West Showa, Ethiopia. Ethiop J Appl Sci Technol. 2017;8(2):84-100.

10. Rhaman MS, Kibria MG, Hossain M, Hoque MA. Effects of organic manures and bio-slurries with chemical fertilizers on growth and yield of rice (cv. BRRI dhan28). Int J Expt Agric. 2016;6(2):36-42.

11. Adesemoye OA, Torbert HA, Kloepper JW. Plant growthpromoting rhizobacteria allow reduced application rates of chemical fertilizers. Microb Ecol. 2009;58:921-29. https://doi.org/10.1007/s00248-009-9531-y

12. Haque MM, Ilias GNM, Molla AH, Impact of Trichodermaenriched biofertilizer on the growth and yield of mustard (Brassica rapa L.) and tomato (Solanum lycopersicon Mill.). Agriculturists https://doi.org/10.3329/agric.v10i2.13148 2012;10:109-19.

13. Sunera, Amna, Saqib S, Uddin S, Zaman W, Ullah F et al Characterization and phytostimulatory activity of bacteria isolated from tomato (Lycopersicon esculentum Mill.) rhizosphere. Microb Pathog. 2020;140:103966. https://doi.org/10.1016/j.micpath.2020.103966

14. Tekalign T, Hammes PS. Growth and productivity of potato as influenced by cultivar and reproductive growth: II. growth analysis, tuber yield and quality. Sci Hortic. 2005;105:29-44. https://doi.org/10.1016/j.scienta.2005.01.021

15. MoARD (Ministry of Agriculture and Rural Development). 2012. Crop Development Department of Crop Variety Register. Issue No. 10. Addis Ababa, Ethiopia.

16. Isreal Z. Potato (Solanum tuberosum L.) growth and tuber quality, soil nitrogen and phosphorus content as affected by different rates of nitrogen and phosphorus at Masha District in Southwestern Ethiopia. Int J Agric Res. 2016;11:95-104. https://doi.org/10.3923/ijar.2016.95.104

17. Mihovilovich E, Carli C, De Mendiburu F, Hualla V, Bonierbale M. Tuber bulking maturity assessment of elite and advanced potato clones protocol. Peru: International Potato Center; 2014.

18. Lung'aho C, Lemaga B, Nyongesa M, Gildermacher P, Kinyale $\mathrm{P}$, Demo P, Kabira J. Commercial seed potato production in eastern and central Africa. Kenya Agricultural Institute. 2007.

19. Kleinkopf GE, Westermann DT. Specific gravity of russet burbank potatoes. Am Potato J. 1987;64:579-87. https://doi.org/10.1007/BF02853760

20. Gomez KA, Gomez AA. Statistical procedures for agricultural research. New York: John Wiley and Sons; 1984.

21. Nityamanjari M. Effect of fertilizers on growth and productivity of potato. Int J Agric Sci. 2018;10(4):5183-86. https://doi.org/10.9735/0975-3710.10.4.5183-5186

22. Isreal Zewide, Tamado Tana, Lemma Wogi, Ali Mohammed. Effects of combined application of cattle manure and mineral nitrogen and phosphorus fertilizer on growth, biomass yield and quality of potato (Solanum tuberosum L.) tuber at Abelo area at Masha District, Sheka Zone, South-Western Ethiopia. Int J Hort Agric. 2018;3(1):1-13. https://doi.org/10.15226/2572 $3154 / 3 / 1 / 00114$

23. Manjunath B, Rajanaika M, Ramesha YM, Yogeeshappa H. Effect of different organic sources of nutrients on physical, chemical and biological properties of soil after the harvest of groundnut (Arachis hypogaea L.). Int. J Agric Sci. 2014;5(2):12126.
24. Teshome A. Effect of $\mathrm{N}$ fertilizer and vermicomposton the growth and quality of potato (Solanum tuberosum L.) in Andercha district, south-western Ethiopia. Mizan: Mizan-Tepi University; 2018.

25. Alam MN, Jahan MS, Ali MK, Ashraf MA, Islam MK. Effect of vermicompost and chemical fertilizers on growth, yield and yield components of potato in barind soils of Bangladesh. Appl Sci Res. 2007;3(12):1879-88.

26. Gurwinder S, Arun K, Gurpreet S, Mandeep K, Mansukh S, Sunita R. Effect of integrated nutrient management on growth and yield attributes of potato (Solanum tuberosum L.). Int J Curr Microbiol Appl Sci. 2018;7(6):2051-56. https://doi.org/10.20546/ijcmas.2018.706.242

27. Fekadu A. Effect of integrated soil amendment practices on growth and seed tuber yield of potato (Solanum tuberosum L.) at Jimma Arjo, western Ethiopia. J Nat Sci Res. 2016;6:1-26.

28. Paul J, Choudhary, AK, Sharma S, Savita S, Bohra, M. Potato production through bio-resources: Long-term effects on tuber productivity, quality, carbon sequestration and soil health in the temperate Himalayas. Sci Hortic. 2016;213:152-63. https://doi.org/10.1016/j.scienta.2016.10.022

29. Sisay Hailu, Tilahun Seyoum, Nigussie Dechassa. Effect of combined application of organic $\mathrm{P}$ and inorganic $\mathrm{N}$ fertilizers on post harvest quality of carrot. Afr J Biotechnol 2008;7(13):2187-96.

30. Bekelech S. Effect of different rates of vermicompost and inorganic NP fertilizers on yield and yield component of potato (Solanum tuberosum L.) at Masha district, south-west Ethiopia. Wollega: Wollega University; 2018.

31. Bhat R, Rashid Z, Dar S, Mufti S. Seed yield and quality parameters of cabbage (Brassica oleracea var. capitata) in relation to different sources and levels of sulfur. Curr Agric Res J. 2017;5(2):177-83. https://doi.org/10.12944/CARJ.5.2.04

32. Seguin P, Zheng W. Potassium, phosphorus, sulfur and boron fertilization effects on soybean isoflavone content and other seed characteristics. J Plant Nutr. 2006;29(4):681-98. https:// doi.org/10.1080/01904160600564477

\section{Additional information}

Peer review information: Plant Science Today thanks Sectional Editor and the other anonymous reviewers for their contribution to the peer review of this work.

Reprints and permissions information is available at

https://horizonepublishing.com/journals/index.php/PST/open_access_policy

Publisher's Note: Horizon e-Publishing Group remains neutral with regard to jurisdictional claims in published maps and institutional affiliations.

To cite this article: Zewide I, Singh S, Kassa $\mathrm{H}$. Biomass production and nutritional quality of potato tuber as affected by blended fertilizer (NPSB), cattle manure, vermicompost and mineral NP in southwestern Ethiopia. Plant Science Today. 2021;8(3):564-571.

https://doi.org/10.14719/pst.2021.8.3.1048

Plant Science Today, published by Horizon e-Publishing Group, is covered by Scopus, Web of Science, BIOSIS Previews, Clarivate Analytics, etc. See https://horizonepublishing.com/journals/index.php/PST/indexing_abstracting 